\title{
Native Relations in Early British North America and the Emergence of Imperial Ideas
}

\author{
Gleb V. Aleksandrov \\ Institute for US and Canada Studies, Russian Academy of \\ Sciences; International Center of Anthropology, National \\ Research University Higher School of Economics, Moscow
}

\begin{abstract}
The article deals with the early evolution of concepts crucial for the development of the British imperial mythology. The author focuses on the emergence of the 'agricultural argument' for appropriating native lands and on the changing perceptions of civility. While the origins of the 'agricultural argument' in the works of early colonial propagandists are obvious, the author argues that those early ideas were not defined enough to serve the purposes of the colonial expansion, and the shift towards a more practical interpretation happened in the context of native-colonial relations. The concept of civility took on new meaning in the colonies, much more similar to the later imperial idea. The author emphasizes the impact of the colonial experience on this ideological evolution.
\end{abstract}

\section{INTRODUCTION}

Imperial history as a part of British history has seen something of a renaissance in recent decades. The 'new imperial history' has introduced the concepts of race, gender and class into imperial studies, but more traditional political, economic and cultural histories are still being written (Ferguson 2002; Nasson 2004; Darwin 2015). There was, of course, some criticism directed towards the new approaches - most of it summarized in an essay by Richard Price (Price 2006; Syriatou 2012), but, while they may lack somewhat in 'traditional' historicism, those new questions have certainly broadened the scope of our understanding of empire in general, and of British Empire in particular. Some proponents

Social Evolution \& History, Vol. 18 No. 1, March 2019 27-46

(C) 2019 ‘Uchitel’ Publishing House

DOI: $10.30884 / \mathrm{seh} / 2019.01 .02$ 
of new imperial history see even greater potential in it - Kathleen Wilson, one of the most widely recognized scholars in the field considers it a way of 'reinventing History itself' (Wilson 2006: 22). The emergence of Atlantic history has also created a new perspective for understanding the Empire, though it also focuses primarily on cultural phenomena, ideas, perceptions and power distribution (Baylin 2005).

However, despite that abundance of existing scholarship, there are still a few 'blank spots' which the new approaches seem to ignore. One can point to the still prevailing Europe-centric perspective while acknowledging the importance of indigenous cultures and their agency is certainly a welcome development, the overall perspective remains in its core a British one - or to the tendency towards viewing the dominant imperial culture as monolithic, lacking any internal diversity (Price 2006; Thompson 2007; Porter 2004). While many aspects of imperial politics, ideas and culture throughout its history have been thoroughly explored, the new imperial history so far did not produce a general historical perspective of its subject. An emphasis on separate narratives, widespread both chronologically and geographically, leaves the issues of development and evolution completely out of the frame of research. It is somewhat telling that the seminal work on the ideological evolution of the British Empire was written by David Armitage, a scholar primarily associated with Atlantic history and intellectual history (Armitage 2000).

Reading the new imperial history, it might almost seem that the British Empire sprang to existence fully formed in mid-eighteenth century. The seventeenth century is almost always forgotten or barely glanced over even in works with a wide chronological and geographic scope (Thompson 2007: 456). The same can be said about the North American colonies. The colonies which formed the core of the United States are almost forgotten - perhaps because traditionally those were regarded as part of American history and were the focus of American historiography. The seventeenth-century North American colonies existed on the periphery of British colonial expansion and still exist on the periphery of imperial history.

We will attempt to explore the role of the North American colonies in the evolution of ideas and concepts of empire in the seventeenth century, focusing on the justifications for appropriation of indigenous lands and the concepts of civility. Both ideas had a long history stretching, in the case civility, all the way to the earliest foundations of the Western civilization. But over time they have changed and evolved, and the ideas which formed the ideological foundations of British expansionism were different from earlier understanding of the same concepts. We will at- 
tempt to trace the evolution of these ideas in the context of American colonies, placing the North American colonies within the general framework of the development of the British imperial narrative. The evolution of both concepts in question was closely connected with native-colonial relations. It was the contact with the Native Americans that forced the colonists to re-examine the existing ideas, and the necessity of establishing relations with the natives was the driving force behind the ideological developments.

\section{SOURCES}

We have used a number of primary sources, broadly divided into two categories - those published in England, including the propaganda pamphlets and treatises on the subject of colonies, and the American ones. Chronologically the earliest ones we examined without relying on existing scholarship are the writings of early colonial propagandists. We used both Hakluyt's 'The Principal Navigations...' and his smaller-scale works, collected in 'The Roanoke Voyages' and 'The Voyages and Colonising Enterprises of Sir Humphrey Gilbert' (Quinn 1938, 1955; Hakluyt 2006, 1890). Samuel Purchas' primary work, 'Purchas his pilgrimage' (Purchas 1612) was originally published in 1612 and had been since published multiple times. We have used pamphlets published in England in the first half of the seventeenth century to promote the New England colonies, 'Good News from New England' and 'New England's First Fruits' (Winslow 2014; New England's First Fruits 1643).

To analyze the ideological developments in the colonies we had to examine a number of works by colonial writers. The most important among them were John Winthrop, one of the founders of the Massachusetts Bay Colony (Winthrop 1908, 1931, 1943) and Roger Williams, the founder of Rhode Island and one of notable religious thinkers of early colonial North America (Williams 2007a, 2007b,). The most prominent missionary in colonial New England, John Eliot, has written extensively, of particular interest to us is 'The Christian Commonwealth' (Eliot 1659), a treatise on his missionary activities. We have used a number of official sources, particularly the colonial records and laws of Massachusetts (Laws of the Colonial... 1832; Records of the Governor... 1853). It should be noted that many of the sources listed were previously unavailable in Russia, but now the vast majority of early colonial literature is available as high-quality scans online. Aside from the works listed above we used a number of texts less important in the context of this article (though some of them are among the key sources in other areas of study). 


\section{JUSTIFYING LAND APPROPRIATION: THE 'AGRICULTURAL ARGUMENT'}

Throughout the article we will periodically reference the British imperial mythology - a complex set of ideas and concepts within the British and colonial cultures used to define the Empire and distinguish it and its people from both native populations of the colonized regions and other European powers. David Armitage has fully explored the key components of what he terms 'imperial fiction' - the British empire saw itself as maritime, Protestant, commercial and free (Armitage 2000). But these broad, general concepts were accompanied by a host of lesser ideas, not as prominent in the imperial consciousness, but necessary to justify and explain particular aspects of imperial politics and colonial expansion. It may be useful at this point to look at the empire as a series of encounters - another approach popular among the proponents of the new imperial history. In each of these encounters the colonists were forced to determine their place in relation to the cultural 'other'. These contact situations produced a number of issues the early colonists in North America had to confront, and, in the absence of a dominant imperial narrative, which emerged later, to solve without referring to any previous experience.

The first and perhaps the most crucial question the colonies faced was a deceptively simple one - do we have the right to be here? The problem, was, of course, the indigenous inhabitants of the colonized areas. What gave the colonists the right to take their lands and, in extremis, exterminate them? It was not, despite the popular stereotype, an easy question. An appropriate legal justification was required, for the sake of other European powers and even other colonies. No less importantly, a moral justification was required, for the sake of the colonists themselves. This was especially important for New England colonists, with their intense self-inspection and the emphasis the Puritan doctrine put on the idea of a covenant as the basis of both society and church.

That same question was first asked decades before the North American colonies were founded. The first time the English had to face it was in Ireland. But, as Armitage (2000: 24-25, 60) points out, the parallels between Ireland and the American colonies are often misleading. The issues encountered by the English in Ireland were different. Yes, the Irish was a traditional 'other' in English culture, the English cultural production of the era made an effort to associate the Irish with savagism and barbarity, to equate the Irish and the Native American (Bach 2000). But this equation could not survive the contact with the Native Americans - for all their differences in language, religion 
and culture, the Irish were much closer to the English in almost every respect, from the perception of gender roles in society to agricultural practices. Ireland was still 'historically' linked - with no small effort on the part of Elizabethan intellectuals - with the Three Kingdoms (Armitage 2000: 27). The Irish land ownership practices were much more similar to the English ones. The justifications that worked for dispossessing the Irish would not work in North America - though the 'Irish approach' was still attempted.

The issue of justifying the appropriation of native lands was also explored, this time specifically in relation to North America, in the writings of early advocates of the colonial enterprise, Richard Hakluyt, Samuel Purchas and Robert Cushman. Their deliberations resulted in a simple and seemingly appropriate answer - the English were perfectly justified in acquiring 'the land which none useth' (Bradford 1622: 68-9), and while it was important to maintain good relations with the natives (Quinn 1938: 185), the 'savages' could not occupy more than a tiny portion of the unexplored continent (Higginson 1908: 46-8).

For thinkers such as Hakluyt and Purchas that answer was sufficient. But in practice it was problematic. The 'vacant land' was a purely fictional construct, lacking any real meaning in a practical sense. The colonists were, of course, familiar with it, but the task of filling the concept with meaning, turning it into a practical principle on which the colonial enterprise could be organized, was left to them.

Theoretical reasoning was insufficient for a number of reasons, the chief one was perfectly simple - there was not much 'vacant' land in North America, at least in the coastal regions. The regions were densely populated, even after the epidemics of 1618-1619. It was a remarkable case of good fortune for the colonists that the early settlers in Plymouth chose the area left barren by the epidemics. It confirmed to their expectations of the 'wilderness', but was far from the norm.

The Indians did not seem to take into account the theory that they 'have no particular proprietie in any part or parcell of that Countrey, but only a generall recidencie there, as wild beasts have in the forrest' (Gray 1609; Belmessous 2015: 48), and stubbornly insisted on the opposite, claiming that the land they inhabit was, in fact, theirs. A number of solutions were proposed by various parties among the colonists, some based on Purchas's and Hakluyt's theoretical approach, some - on the previous experience of colonial leaders in Ireland. Some scholars have traced a direct line of succession from earlier thinkers to John Locke (Banner 2005: 36; Armitage 2000: 64; Cave 2011: 1), Locke's ideas incorporated directly into the British imperial 
ideology (Armitage 2000: 97; Flanagan 1989). The ideological construct of 'vacant land' was challenged by several alternatives, and had evolved and developed before it was co-opted by 'mature' imperial ideology, and that evolution took place in the colonies.

The first solution to the problem of justifying the settlement of America was the simplest one (and it was, in fact, used by both Britain and the US in later centuries with rather more success) - the right of conquest. Yes, the Indians may insist on owning their land, and the colonists may even recognize that right as legitimate, but there are numerous precedents for wars of conquest in Europe, and no one can stop the colonists from taking what land they need by force. This solution was proposed by William Symonds (Symonds 1609: 10) and was, to a degree, attempted in Virginia. To a degree - because from the very start it was not supported by all of the colonists and even all the colonial leaders. Its primary proponents were the military men of the Virginia Company, the veterans of the Irish campaigns. They were sure that the 'savage natives' are inherently treacherous, any attempt to deal with them civilly is doomed, and force is the only way to ensure the continued existence of the colony (for a full exploration of struggles over Indian policy in early Virginia see Cave 2011). The idea was in direct opposition to both Hakluyt's position on native relations and land appropriation and the 'instructions' the colonists received from the Company (Quinn 1938: 217-219; 1955: 259-288). Besides moral objections, there were practical ones - the colonies were simply not equipped to fight the natives on a large scale and were incapable of conquering them. As much as the veterans might dream of replicating their earlier success, it was not realistically possible. Nevertheless, the idea of direct conquest found some support, and on a few occasions was attempted explaining the abundance of native-colonial conflicts in early Virginia and the colony's inability to establish long-standing profitable relations with the neighbors for decades to come (Cave 2011).

There was another possible ideological foundation for appropriating native lands, a religious one. The Christians, according to its proponents, were entitled to the land by virtue of being Christian. The question of native property rights was thus circumvented - it did not matter if the Indians owned the land, their property rights were inherently inferior to Christian ones. Perhaps surprisingly, considering the intense religiosity of the Puritans, this was a minority position even in New England, was heavily criticized (Belmessous 2015: 48; Williams 2007: II, 120) and was discarded relatively quickly. The reason may be the distinct differentiation between the religious and the mundane in puritan mindset - securing lands for the colony was an administra- 
tive matter to be conducted by peaceful means. Maybe the colonial leaders perceived a clash between this justification and the possibility of converting the natives - while it has been shown that the New England colonists were not particularly concerned with missionary duties, converting the natives was a stated goal of the colonies and an important propaganda tool aimed at investors in England. Proclaiming the desire to convert the natives while simultaneously using the fact they were pagans to justify expansion could lead to confusion and discredit the colonies, especially in the absence of actual large-scale missionary efforts.

The third approach examined and attempted by the colonists, much more in vein with Hakluyt's sentiment, was to buy the land. Acknowledging that the Indians owned the land the colonists could rightfully purchase it. The chief proponent of this idea was, of course, Roger Williams, who supported this position in his writings, in his arguments with the Massachusetts Bay Colony authorities, and in practice, purchasing the land from the Narragansett to establish the Rhode Island colony (Williams 2007: II, 44-7; IV, 461). This approach was not accepted by the majority of the colonists in its entirety - Williams attempted to question the royal authority, insisting that the Indian land rights hold precedence over the King's charters (Banner 2005: 46). Nevertheless, in general it seemed to work for a while, and purchasing land was one of the main mechanisms of colonial expansion (Ibid.: 10-49). Whether such purchases were entirely transparent, the terms were fair and the Indians understood those terms is another set of questions entirely, but purchasing native lands was generally accepted. Already it was a departure from earlier ideas, since the colonists did not occupy 'vacant' lands. But the idea of terra nullius was soon invoked again, and again further examination of the idea was driven by practical experience. While the colonists seemed to accept on moral grounds the necessity of purchasing the land from the natives, the question they faced now was what does 'owning land' mean?

Royal charters granted the colonists patents to land and prevented, at least in theory, conflicts with other English colonies and other European powers. The natives who occupied those lands were agreeable to selling some portion of it for the appropriate price. But the colonies were expanding rapidly. Purchasing the land was expensive, and, to further stress the dilemma, the modes of production and the understanding of ownership in different cultures were far from similar. There were vast stretches of land left seemingly unused, but the Indians stubbornly insisted it was their land. While the colonists conceded 
to the idea of Indian property, they were not prepared to pay for the land that was clearly not used at all.

The theory clashed again with the practice. The colonists would occupy those 'untamed' lands in any case, that become clear rather quickly (Cotton 1634: 4; Banner 2005: 40, 53), and the leadership was faced with a dilemma. They could not stop the appropriation of native lands, nor did they wish to. But appropriation without proper justification would cast doubt upon the legitimacy of the whole enterprise, both in legal and moral terms. The latter was perhaps even more important for New England Puritans, permanently concerned with godliness of their actions and their own sinfulness. If they appropriated the land in an amoral, ungodly way, that is they were cruel and unrighteous, how could they claim the righteousness of the rest of their 'great experiment'? The writings of Puritan divines and colonial leaders, the sheer amount of discussions of the issue, the public confrontation with Williams (examined thoroughly in [Jennings 1976]) show quite clearly that it was not a question to be answered easily, and the Indian property rights were not a minor issue. It was a major problem for the colonial government and the colonial worldview, and the long-held idea that the colonists believed the natives possess no land rights (Williams R. A. 1990: 221; Seed 2001: 12-44) is false. That idea was used as a justification for denying native lands by the US courts since the Johnson $v$. McIntosh case. Unlike many old pieces of legislation, Johnson $v$. McIntosh remains a law and is still invoked in American courts every year (Banner 2005: 11; US Supreme Court, 1823).

The solution was to redefine 'vacant land', so the problem would cease to be the one of property rights. The natives would still possess property rights, but only to the land they cultivate. It would be unlawful and immoral to rid the poor 'savages' of their livelihood (Winthrop 1931: 106-49; The Original Rights... 1722: 6), so the lands used for agriculture were obviously off-limits for direct appropriation and had to be purchased. But the rest the natives do not cultivate, therefore they cannot claim any meaningful ownership of it. Owning the land means improving it, separating it from the wilderness, both in a metaphorical sense through establishing clear borders (Seed 1995), and physically, by using it for production. But - argued Williams, and many colonists have undoubtedly observed themselves - they do cultivate it, albeit not in the same way the English do. The natives certainly do improve their hunting grounds (e.g., Williams 2007, II: 467). Colonists were familiar with native practices of caring for berry patches and oyster banks and clearing the underbrush to facilitate big game hunting. The answer was, of course, that the Indians do not cul- 
tivate the land properly. They do not enclose it, do not use it to produce crops, therefore, they are clearly incapable of improving most of the land they 'own' in a godly and civilized manner, and their claims of ownership are to be ignored. Owning land meant caring for it and improving it in a certain and relatively specific way. The idea, first articulated by John Winthrop and his compatriots (Winthrop 1931: 106-49; Williams 2007: II, 44-7; Young 1970: 272-76), that served so well in defeating Roger Williams in an argument, became such a potent tool that soon it was not only accepted as a part of colonial propaganda literature, but was incorporated into the Massachusetts Bay Colony laws (Laws of the Colonial and State Governments 1832: 9-10). It took its final shape only after it was refined to define cultivating the land as cultivating it in a specific English manner. It is important to note that the link between cultivation and ownership, while present in some earlier discourse on the topic, was not used in England itself and was specifically addressed and expanded in colonial context - in England uncultivated land could still be owned, of which early colonial thinkers were undoubtedly aware. Ownership through different types of activities, aside from cultivation, was also widely discussed and generally acknowledged (Selden 1972: 24-7).

This 'agricultural argument' was later used as a justification for appropriating native lands throughout the British Empire, albeit in a slightly more refined version. That refined version, attributed to John Locke, is generally accepted to be one of major ideological foundations of colonial expansion (Armitage 2000: 97; Tully 1993: 169). Locke scholars even admit that he developed it on the basis of earlier puritan writings (Tully 1993: 150). However, in the context of imperial history this point seems curiously absent. Even Armitage, while presenting a thorough analysis of Hakluyt's and Purchas' work and of Locke himself, barely mentions any of those discussions or their influence on Locke (Armitage 2000: 97-8). Nor, it seems, anyone questions the degree to which the argument was accepted in the seventeenth century metropole. It is worth noting that in 1665 the visiting officials from London had to remind the colonial officials that 'no doubt the country is theirs till they give or sell it, though it be not improved' (Shurtleff 1853, 4(2): 213).

We would like to draw attention to three key points. Firstly, earlier works do not contain the agricultural argument in its entirety, if at all, for their authors the problem of defining vacant land in terms of production practices is clearly of secondary concern. To derive Locke's sophisticated and refined argument directly from them is to miss a crucial stage of its development. The difference between 'vacant land', a sim- 
ple dichotomy of cultivated or uncultivated land, and the importance of a specific way of cultivating it, improving it and establishing ownership is a crucial one. If anything, Locke's argument is a somewhat simpler version, less well suited for imperial purposes than the one codified in the laws of the Massachusetts Bay Colony. Secondly, there was no single clear line of the development of early colonial ideas, from more to Hakluyt to Winthrop to Locke. Hakluyt's model, the bestknown one, was only one of the justifications 'tested' by the colonists, and in its original form it was no more successful than the right-ofconquest argument or religious justification. The agricultural argument later adopted by Locke and disseminated throughout the Empire in centuries to come was the result of a conjunction of earlier ideas, Puritan introspection and adaptation to colonial conditions. Thirdly, to understand it one must look at the conditions of its emergence. Purely theoretical constructs proved unable to provide a satisfactory ideological foundation for colonization. The idea necessary for imperial development was forged by the colonial experience, and was most thoroughly expressed in the legal documents. This illustrates perfectly that trying to derive imperial ideas from purely English context is futile. Without the colonial experience they remained empty theoretical constructs.

The question of legitimacy of native production practices however did not end with justifying land appropriation. Indian agriculture and Indian way of life in general had a significant impact on the evolution of another concept, that of civility.

\section{CIVILITY, SAVAGISM AND THE NEW ENGLAND MISSIONARIES}

The concept of civility is one of the cornerstones of the imperial idea and some would argue the entire western civilization. The dichotomy between civility and barbarity is rooted in ancient Greek and Roman traditions, and the terms themselves have persisted throughout European history, were examined by some of the key thinkers, from Aristotle to Erasmus. Of course, the history of the concept is rich, and its meaning has changed over time. Or rather, as Fitzgerald (Fitzgerald 2007) has shown, civility is not so much a single concept as a whole 'cloud' of concepts, with a host of meanings used throughout the centuries. For a Greek philosopher, a Middle Ages religious scholar and a late eighteenth century colonial propagandist civility meant different things, and all three were probably different from civility as understood by a common individual in any of these eras. The question we must address first is what civility meant for the European colonists in 
the seventeenth century North America, their immediate predecessors and their imperial descendants.

The opposition of civility and barbarism was a key point in colonial propaganda throughout the sixteenth century. It was used to contrast the civil English and Lowland Scots and savage or barbarous Highlanders and Irish. It was also used extensively in Hakluyt's work applied to the Native Americans. The meaning of civility was in those cases different. Both originated from the medieval discourse on civility (explored thoroughly in Fitzgerald 2007). Within it, civility was defined primarily as the presence of laws and social hierarchy. The savages lived 'as wild beasts', with no laws and no government. This approach was paralleled and developed later by Locke and other Enlightenment thinkers as the idea of 'state of nature', and in this form persevered well into the eighteenth century, to appear later in European and American discourse - including, for example, the writings of Thomas Jefferson (Jefferson 1787: 150). But civility as social organization was entirely unsuitable for propaganda purposes, especially concerning the difference between the English and the Scots and Irish - because both 'barbarous' nations obviously had social organization, had rulers and laws and their structure was obviously similar to English. Throughout the sixteenth century a new meaning of civility started to emerge, incorporating the ideas of manners, propriety and good breeding. This process, explored by Anna Bryson (Bryson 1998) was neither instantaneous nor all-encompassing, and the two notions of civility coexisted for centuries.

But when the concept of civility was applied to North America this shift was less obvious. Early authors, such as Hakluyt and Peter Martyr were quite happy to stick with the older interpretation of civility as a lack of social order and law, and to claim that Native Americans possessed neither, living in a completely natural state of being (Arber 1971: 69-78; Hakluyt 2006: 327-40; Quinn 1985: 50). It was a convenient framework for exploring the civilizing mission of the colonies. Civility as manners was not absent from colonial accounts or Hakluyt's work itself, but quite often this form of civility was attributed to the natives. They were polite, gentle and civil in their behavior, but lacked civility in the social sense (Taylor 2010: 76, 164-65; Eburne 1962: 55-6).

This civilizing drive was of course connected to missionary activity. Hakluyt himself, an ordained priest, paid remarkably little attention to the idea of spreading the Lord's word to heathen natives. But others did - Purchas advocated for missionary activity rather directly (Purchas 1612), and it was, of course, a major point of the early seven- 
teenth-century colonial propaganda (White 1630; Winslow 2014: 14, 19; New England's First fruits 1643: 5-12).

According to Fitzgerald, from very early on, Christianity outside the high-minded academic theology and individual spiritual experience was constructed primarily through ostensibly 'external' means - law, customs, everyday practices (clothes, hairstyles, etc.) (Fitzgerald 2007: 119). In the seventeenth century, Purchas perhaps understood it better than anyone, seeing the civility, the proper organization of a civic society, as not a by-product, but a goal of religion (Ibid.: 203). One might theorize that Hakluyt saw that link very clearly - he did not need to advocate missionary activities as separate from civilizing ones.

Fitzgerald postulates (Ibid.: 119) that such was the approach of Christianity as a whole, that every missionary effort was a civilizing one and vice-versa. While it may be so if one examines said activities from a very broad historical perspective, in the context of the sixteenth-seventeenth centuries the idea seems doubtful. At the very least, catholic missionaries in Canada were quite happy to spread the good word, but leave the natives way of life intact, going as far as to incorporate native rituals into everyday practice of catholic religion.

The early decades of the seventeenth century were a crucial period for the development of civility as a concept. In fact, according to Bryson (1998) this was the time than the 'official', the articulated and analytic, interpretation of civility in a political context changed to incorporate the ideas of manners and good breeding. The concept has evolved, as was the case with the agricultural argument in the colonies, out of necessity. In England, it was needed to justify the continuing divide between the English and the Gael in Ireland and Scotland and later to explain the 'deficiencies' of the poor, the primary target of English missionary activity.

When first settlers bound for Virginia and New England were preparing to leave their homeland they possessed a mix of ideas about civility, what it meant, what it was, and how it was linked with religion. To further complicate the matters, different interpretations of civility were not codified, and those writing about it were undoubtedly influenced by the whole complex of ideas, elements of different interpretations coexisted within one text, authors rarely subscribing completely to a certain interpretation. It is still possible, though, to talk about the dominant one in each particular case.

Understanding of civility had evolved in the colonies at the same time it was evolving in England, but in a different way. After coming into contact with the natives, the English were forced to adjust their notions of civility accordingly and to re-examine their missionary 
goals and methods. The idea that the natives did not have civil society was eventually cast aside. The reasons were numerous, but the primary one was that it was obviously false. The Indians clearly had rulers, laws and other 'required' social features. In fact, it was necessary for them to have those for the colonies to exist. This is one of the contradictions in Hakluyt's work the author himself either did not notice or choose to ignore - if the Indians do not have proper society and laws, they clearly cannot have property, even though Hakluyt advocated buying land from them if necessary. They clearly can make no 'diplomatic' decisions, even though Hakluyt advocated allying with them, possibly against the Spanish (Hakluyt 2006). If the colonies wanted to buy land, they had to sign a contract, and if they wanted to make peace, they had to acknowledge they are making peace with someone, thereby implicitly acknowledging that the natives have some form of government, and have, therefore, civility. For Hakluyt this contradiction was not an issue, it did not hinder his overarching narrative, but for the colonists it became a problem.

The introspection was rather wide. The colonists were forced to define not only Indian barbarity, but English civility. They knew that some colonists were prone to 'going native', abandoning they settlements and living with the natives, or at least becoming lazy, insolent and insubordinate. Such colonists, shunned and feared by the authorities, have obviously lost something, some inherent quality of the Europeans, especially the English. That elusive quality became known as civility. It was more than manners, though the manners of these unfortunate strays definitely changed, and it had little to do with social organization. It was not defined by their place in traditional society any colonists place in this society was somewhat unclear and shaky, due to the very fact that while remaining English, they were certainly different in their ways of live and worldview from the 'mainland' English. Their own civility was called into question by those in the homeland (Bach 2000: 115, 120-24), further stressing the need for a more coherent understanding. Civility was what defined them as opposite to savages, but what exactly was it?

Ruth Frankenberg (Frankenberg 1993: 194) defined civility in colonial discourse as 'white cultural practice'. This is a fruitful idea. Cultural practice is a broad term, a simple way of distinguishing 'us' from 'them' that does not require a clear definition. The association with racial categories, crucial for the later stages of ideological development was not as important in the early colonial context. In fact many of the early colonial propagandists argued against such ideas as both inhumane and detrimental to the very idea of the colonial enter- 
prise - if the natives are inherently inferior and cannot be elevated to the civilized status, the whole moral point of colonization would be questionable. But defining civility as a set of cultural practices allowed avoiding this problem. This definition of civility, while substantially less precise when both previous approaches (civil society or manners), suited the colonists perfectly. And it found its expression in their missionary practice.

Contrary to the aforementioned propaganda pamphlets, missionary work was not an important goal for the colonists themselves, at least not in terms of converting the natives. While Puritan preachers were remarkably active, their efforts were primarily directed at maintaining the godliness of the congregation, weeding out the unrighteous, driving the public to strive for religious perfection (Anderson 1991: 177-222). The primary targets of the civilizing effort, of maintaining the civil cultural practice, were the colonists themselves. Proselytizing among the natives remained a pursuit for a few enthusiastic volunteers, most relatively new to the colonies and not as closely tied to the original Puritan community transplanted from England.

Of course, and when given the chance, Puritan 'diplomats' did not miss a chance to explain their religion to native allies, but those were solitary cases, not a result of an organized missionary effort. The situation only changed appreciably after the arrival of John Eliot, 'apostle to the Indians'. Eliot was a gifted orator, capable of inspiring the public. More importantly, he addressed the Indians in their own language which Roger Williams did as well, but Williams was far too preoccupied with both his religious studies and practical affairs of trade and later establishing a colony to be a consistent missionary. Eliot introduced writing to the Indians, in the form of the first printed bibles and catechisms in Algonquian. But the biggest of his accomplishments was the praying towns project.

In Eliot's view, the native way of live, the native cultural practice in its entirety, was incompatible with Christianity. In his praying towns the converts lived in European-style houses, performed agricultural and other domestic tasks according to European standards - men working in the field, women at home (as opposed to native division of labor, where agriculture was a woman's task, while the men hunted), dressing and cutting hair in European fashion. They would even have their own justices of peace and administrators, slowly absorbing the most important part of civility - the ability to organize themselves, to obey the rules of society. Thus civilized, the natives would be capable of learning, both reading and writing and counting and of course the Scripture and, eventually, they would reach a point of true conversion 
and becoming members of the Church. But even with Christianity as the ultimate goal, civility was not distinctly Protestant in nature - no one would claim that French or Spanish were not civilized, they just have chosen the wrong religion. The natives had to be first brought to a point there they can consciously make such a choice. This is profoundly different from any missionary efforts accepting the native way of live (Catholic in Canada) or creating a different, separate one for them (Catholic in South America).

Eliot's project, despite lackluster support from the colonial government, was a qualified success. He managed to accumulate a significant number of converts and established seven praying towns. The reasons for Indians accepting praying towns were diverse and not all of them genuinely converted. Eliot even convinced the officials to grant the praying towns a degree of autonomy in internal matters, with local magistrates and courts conducted in native languages - though still European in form.

Eliot's project disintegrated during King Philip's War and the praying towns were never completely rebuilt. The reason was the lack of trust towards the natives from the majority of the colonists. Eliot's converts were still savages, and could not turn into proper civilized Englishmen in just a few short years, after all.

Nevertheless, it had consequences further down the line. Eliot's program, in which Christianity and European civility in its broad, colonial sense, became a model for future missionaries, and undoubtedly influenced both the Indian schools of the nineteenth century and the reservation system. But in the context of the British Empire specifically they also became something of a model.

Spreading civility became a key feature of imperial imagery throughout the British world. Later missionary efforts were far more concerned with civilizing, not converting the natives (Fitzgerald 2007: 306-7; Roy 2005; Coleman 2006: 3-6; MacCoinnich 2015). The religious component itself came in to play later, if at all. The civility the British empire spread throughout the world was not a civic state of being or the manners and good breeding (Armitage 2000: 38; Bach 2000: 113-49; MacCoinnich 2015: 14; Jonson 1816: 235-44). The imperial civility was that same complex of white cultural practice defined, articulated and spread by Eliot.

The question 'what makes them savage?' can be phrased as 'what makes us civil?' There were several cases of colonists abandoning their civility 'going native', so this second aspect was probably even more important for the majority of the colonists. While Eliot and other missionaries were concerned with spreading civility, the task of colo- 
nial leadership was maintaining it (Coleman 2006: 47). The Puritans were willing to tolerate religious divergences - to an extent, they did not accept Catholics among them for a long time, and would probably not accept Muslims - but were willing to tolerate other protestant denominations, as long as they kept themselves civil, that is maintained the appropriate cultural practice. The Quakers were persecuted (Pestana 2004) not because of doctrinal differences, but because they eschewed social conventions, allowing women to preach and behaving in a completely inappropriate way. They became the 'other', much as the Indians were, by denying their own civility. Those who refused to maintain other aspects of cultural practice - French traders living as 'half-Indians' (Mather 1853: 595) or lazy proprietors who refused to cultivate their land properly, have lost their civility (Coleman 2006: 54-5). Eliot's ultimate goal was to use the praying towns as a model for a godly society to be established in England itself (Eliot 1659: 1-18). While this idea seemed too radical at the time, and Eliot was forced to remove it from later editions of the book, it found parallels in imperial experience - in the efforts to 'uplift' the poor in England itself, treating them ostensibly as objects of missionary activity, cultural more so than religious (Darwin 2013: 305-17).

\section{CONCLUSIONS}

The British imperial ideology was a complex set of ideas. In the seventeenth - early eighteenth century the Empire was perceived as protestant, maritime, mercantile and free. Free in a political sense, and even so never absolute - it was still a monarchy, but the idea that the British citizens enjoyed a degree of political and individual freedom impossible in any other state was important nonetheless. Later other ideas emerged, though none of the key concepts disappeared completely. The strictly mercantile nature of imperial expansion was largely disregarded, and extensive land acquisitions supplemented and eventually replaced naval dominance. The idea of the civilizing mission of the Empire grew in importance. New aspects of the imperial image have emerged, like the perceived technological superiority of Britain over the potential colonies and other European powers. It was an image of the Empire as an ultimately benevolent global force, it's very existence and its occasional use of violence justified by the ultimate good of humanity - including the 'ungrateful savages'. Both acquiring land and spreading imperial culture required a moral justification. The agricultural argument and the concept of civility became the foundations of this mature imperial idea. 
The two concepts were separate, but certainly connected. The differences in production in the heart of the agricultural argument was used as a justification for appropriating native lands, and was an important part of civility as understood by the colonists - as a set of cultural practices. Both those concepts, the agricultural argument and civility as a set of cultural practice emerged in the North American, primarily New England, colonies, in the first half of the seventeenth century. Both used earlier ideas, but the specific shape they took was determined primarily by the colonial experience, particularly by the contact with a drastically different native culture. This contact, the close and prolonged communication with the cultural 'other', impossible in England or, indeed, in Europe in general, and the practical necessities of establishing relations with the native population of North America were the primary driving force of this ideological development. They required cultural introspection and a re-examination of established ideas. Those ideas themselves, mostly purely theoretical before the establishment of the colonies, could not provide sufficient ideological foundation for colonization. The emerging imperial myth had to incorporate those colonial developments to serve its primary purpose of justifying the continued colonial expansion and subjugation - while it was certainly refined and expanded in England, its roots, by necessity, were in the colonies.

\section{REFERENCES}

Anderson, V. 1991. New England's Generation. Cambridge: Cambridge University Press.

Arber, E. (ed.) 1971. The First Three English Books on America, 1511-1555. New York: Kraus Reprint.

Armitage, D. 2000. The Ideological Origins of the British Empire. Cambridge New York: Cambridge University Press.

Bach, R. 2000. Colonial Transformations: The Cultural Production of the New Atlantic World, 1580-1640. New York: Palgrave.

Bailyn, B. 2005. Atlantic History: Concept and Contours. Cambridge, Mass. - London: Harvard University Press.

Banner, S. 2005. How the Indians Lost Their Land: Law and Power on the Frontier. Cambridge, Mass. - London: Belknap.

Belmessous, S. 2015. Empire by Treaty: Negotiating European Expansion. Oxford - New York: Oxford University Press.

Bryson, A. 1998. From Courtesy to Civility: Changing Codes of Conduct in Early Modern England. Oxford: Oxford University Press.

Cave, A. 2011. Lethal Encounters: Englishmen and Indians in Colonial Virginia. Oxford: Praeger. 
Coleman, D. 2006. White Civility: The Literary Project of English Canada. Toronto: University of Toronto Press.

Cotton, J. 1630. God's Promise to His Plantations. London. URL: http:// digitalcommons.unl.edu/cgi/viewcontent.cgi?article $=1022 \&$ context $=$ etas. Accessed November 6, 2018.

Darwin, J. 2013. Unfinished Empire: The Global Expansion of Britain. London: Bloomsbury.

Eburne, R. 1962. A Plain Pathway to Plantations. Ithaca: Cornell University Press.

Eliot, J. 1659. The Christian Commonwealth: or, The Civil Policy Of The Rising Kingdom of Jesus Christ. London: Livewell Chapman.

Ferguson, N. 2002. Empire: The Rise and Demise of the British World Order and the Lessons for Global Power. New York: Penguin Books.

Fitzgerald, T. 2007. Discourse on Civility and Barbarity. Oxford - New York: Oxford University Press.

Flanagan, T. 1989. The Agricultural Argument and Original Appropriation: Indian Lands and Political Philosophy. Canadian Journal of Political Science 3: 589-602.

Frankenberg, R. 1993. White Women, Race Matters: The Social Construction of Whiteness. Minneapolis: University of Minnesota Press.

Gray, R. 1609. A Good Speed to Virginia. URL: https://quod.lib.umich. edu/e/eebo/A02059.0001.001?view=toc. Accessed November 6, 2018.

Hakluyt, R. 2006. A Discourse Concerning Western Planting. URL: http:// nationalhumanitiescenter.org/pds/amerbegin/exploration/text5/hakluyt.pdf. Accessed November 6, 2018.

Hakluyt, R. 1890. The Principal Navigations, Voyages, Traffiques and Discoveries of the English Nation. URL: https://archive.org/details/theprincipalnavi 25645gut/page/n5. Accessed November 6, 2018.

Higginson, F. 1908. New-England's Plantation. URL: https:/archive.org/details/ newenglandsplant00higgrich/page/n9. Accessed November 6, 2018.

Jefferson, T. 1787. Notes on the State of Virginia. URL: https://docsouth.unc. edu/southlit/jefferson/jefferson.html. Accessed November 6, 2018.

Jennings, F. 1976. The Invasion of America: Indians, Colonialism and the Cant of Conquest. Chapel Hill - New York: Norton.

Jonson, B. 1816. For The Honor of Wales. In The Works of Ben Jonson. 9 Vols. Vol. 7. (pp. 329-348). London.

U.S. Supreme Court. 1823. Johnson v. McIntosh. URL: https://supreme.justia. com/cases/federal/us/21/543/\#. Accessed November 6, 2018.

U.S. Supreme Court. 1832. Laws of the Colonial and State Governments, Relating to Indians and Indian Affairs. Washington: Thompson and Homans. URL: https://archive.org/details/lawscolonialand00statgoog/page/n4. Accessed November 6, 2018.

MacCoinnich, A. 2015. Plantation and Civility in the North Atlantic World. Leiden - Boston: Brill.

Mather, C. 1853. Magnalia Christi Americana. Hartford, CN: Silas Andrus \& Son. 
Nasson, B. 1643. New England's First Fruits: With Divers Other Special Matters Concerning that Country. URL: https://archive.org/details/NewEnglandsFirst FruitsInRespectFirstOfTheCounversionOfSome/page/n0. Accessed November 6, 2018.

Nasson, B. 2004. Britannia's Empire: Making a British World. Gloucestershire: Tempus Publishing.

Pestana, C. 1991. Quakers and Baptists in colonial Massachusetts. Cambridge New York. Cambridge University Press.

Price, R. 2006. One Big Thing: Britain, Its Empire and Their Imperial Culture. Journal of British Studies 3: 602-627.

Purchas, S. 1612. Purchas, His Pilgrimage; or, Relations of the World and the Religions Observed in All Ages. URL: https://archive.org/details/purchashispilgri00 purc/page/n5. Accessed November 6, 2018.

Quinn, D. (ed.) 1938. The Voyages and Colonizing Activities of Sir Humphrey Gilbert. Vol. 1. London: The Hakluyt Society.

Quinn, D. (ed.) 1955. The Roanoke Voyages, 1584-1590. Vol. I. London: Hakluyt Society.

Quinn, D. (ed.) 1985. Set Fair for Roanoke: Voyages and Colonies, 1584-1606. Chapel Hill: UNC Press.

Roy, A. (ed.) 2005. Civility and Empire: Literature and culture in British India, 1822-1922. London - New York: Routledge.

Seed, P. 1995. Ceremonies of Possession in Europe's Conquest of the New World, 1492-1640. Cambridge - New York: Cambridge University Press.

Seed, P. 1995. 2001. American Pentimento: The Invention of Indians and the Pursuit of Riches. Minneapolis: University of Minnesota Press.

Selden, J. 1972. Of the Dominion, Or, Ownership of the Sea (London, 1652). New York: Arno Press.

Shurtleff, N. (ed.) 1853. Records of the Governor and Company of the Massachusetts Bay in New England. URL: https://archive.org/details/recordsofgoverno 01mass/page/n7. Accessed November 6, 2018.

Symonds, W. 1609. Virginia: A Sermon Preached at White-Chappel. URL: https://scholarscompass.vcu.edu/cgi/viewcontent.cgi?article=1001\&context=b ritva. Accessed November 6, 2018.

Syriatou, A. 2012. National, Imperial, Colonial and the Political: British Imperial Histories and their Descendants. Historein 12: 38-67.

Taylor E. (ed.) 2010. The Writings and Correspondence of the Two Richard Hakluts. Abingdon: Routledge.

1722. The Original Rights of Mankind Freely to Subdue and Improve the Earth. Available at https:/quod.lib.umich.edu/cgi/t/text/text-idx?c=evans; idno= N01974.0001.001 (accessed November 6, 2018).

Thompson, J. 2007. Modern Britain and the New Imperial History. History Compass 5: 455-462.

Tully, J. 1993. An Approach to Political Philosophy: Locke in Context. New York: Cambridge University Press. 
White, J. 1630. The Planters Plea. URL: http://name.umdl.umich.edu/A15097. 0001.001. Accessed November 6, 2018.

Williams, R. 2007a. The Complete Writings of Roger Williams. Vol. II. Eugene, Ore.: Wipf \& Stock.

Williams, R. 2007b. The Complete Writings of Roger Williams. Vol. IV. Eugene, Ore.: Wipf \& Stock.

Williams, R. A. 1990. The American Indian in Western Legal Thought: The Discourses of Conquest. New York: Oxford University Press.

Wilson, K. (ed.) 2004. A New Imperial History: Culture, Identity, and Modernity in Britain and the Empire, 1660-1840. Cambridge - New York: Cambridge University Press.

Winslow, E. 2014. Good News from New-England. Cambridge, Mass.: University of Massachusetts Press.

Winthrop, J. 1931. Winthrop Papers. Vol. II. Boston: Massachusetts Historical Society.

Winthrop, J. 1943. Winthrop Papers. Vol. III. Boston: Massachusetts Historical Society.

Winthrop, J. 1908. Winthrop's Journal. New York: Charles Scribner's Sons.

Young, A. (ed.) 1970. Chronicles of the First Planters of the Colony of Massachusetts Bay 1623-1636. New York: Da Capo Press. 